\title{
When Blood Won't Tell: Integrated Transfusions and Shifting Foundations of Race
}

\section{Susie Woo}

On May 29, 1956, nurses climbed aboard USS Lake Champlain to collect a thousand pints of crew member blood. A US military photographer was on hand to document the event, not because blood drives were rare but rather to spotlight a marked change. In the single shot selected for print, the photographer captured the moment of exchange between a white nurse and the only African American navy man in line [Figure 1]. The image was part of a series of military photographs taken during the 1950 s intended to chronicle an integrated army. However, despite the photographer's objective to offer visual evidence of purportedly seamless racial integration, the image could not contain the awkwardness of that blood drive. To keep her bodily distance, the nurse fully extends her arm to give the African American man the vial; her white hands nearly but, importantly, do not touch his black hands-both visible strains that more accurately represent the stutter steps of desegregation. Perhaps most revealing is the unhappy expression of the seaman instructed to hold his pose and the firm gaze of the second nurse who peers through her glasses to stare at the man whose blood will only be marked by type, not by race.

The American Red Cross (ARC) integrated the national blood supply in 1950. For the first time on a large scale, blood moved indiscriminately between differently raced bodies. By the end of the Korean War in 1953, tens of thousands of US servicemen returned home with racially anonymous transfused blood coursing through their veins. And given the continual need for blood 


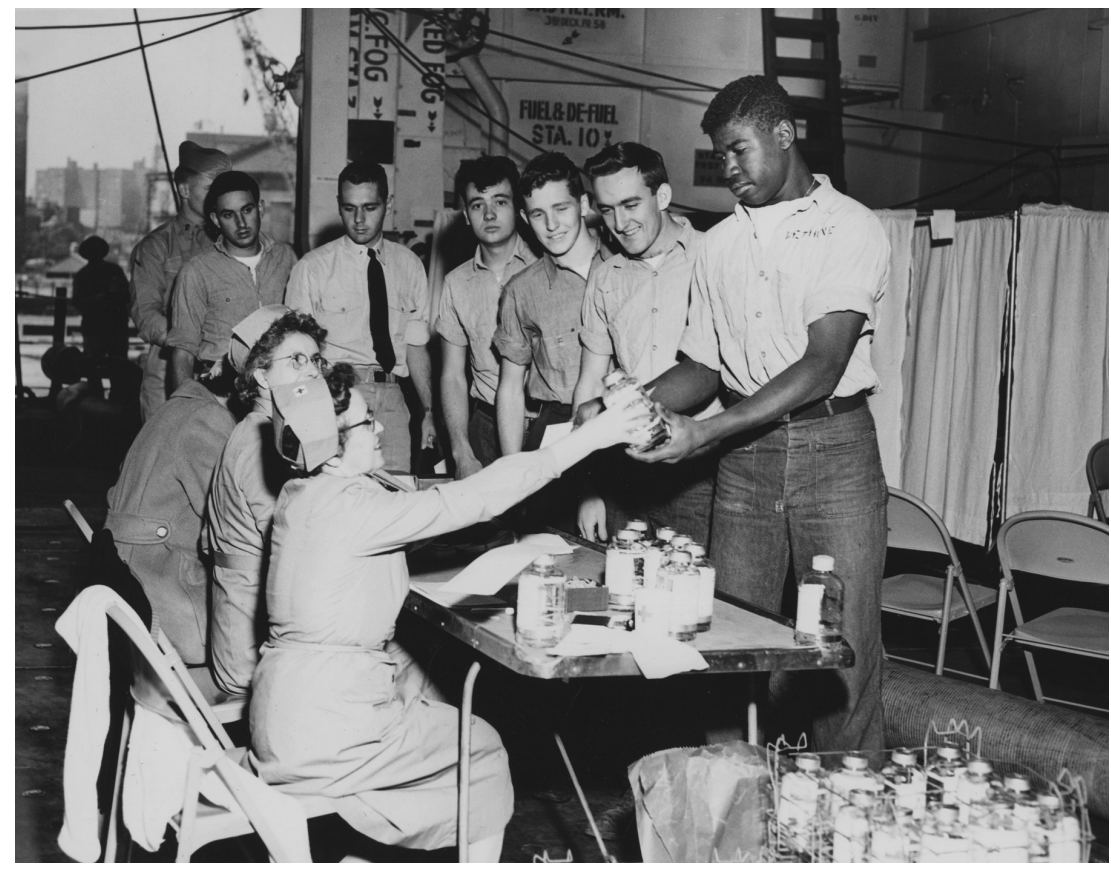

Figure 1: Official photograph, US Navy, USS Lake Champlain, May 29, 1956, CVA-39-4595, Military Photographic Collection, Schomburg Center for Research in Black Culture, New York Public Library.

in hospitals across the nation, researchers estimated that the integrated supply would reach millions more in the decades to come. ${ }^{1}$ Despite efforts to show otherwise, the photograph shown in Figure 1 could not contain the significance of mixing the national blood supply, of allowing black blood to travel freely into white bodies. The tension in the photograph signaled the challenge of narrating transfusions after 1950. Once the ARC desegregated blood, conversations about transfusions required careful management, for blood carried with it deeprooted associations as well as the legal power to determine who had access to citizenship, property, and marriage.

This essay considers what happened to blood at this moment of change. It traces how blood - so central to conversations about race for decades - receded into the background by the 1950s. Beginning with civil rights protests against the ARC's blood-segregating policies during World War II and ending with the National Blood Program's (NBP's) rescripting of blood during the Korean War (1950-1953), the essay explores how Cold War and civil rights pressures converged to reconfigure blood as a less potent symbol of race. After the ARC desegregated blood, the NBP's publicity council, organizations like UNESCO, and mainstream media actively ushered conversations about race away from blood. Together, they narrated transfusions in ways that changed popular as- 
sumptions about blood, downplayed the significance of its mixture, and helped drive race-identifying practices away from the body altogether.

After its integration, blood would never be quite the same. Blood symbolized too much yet not enough all at once. The malleable, nonvisible, and manipulatable fluid had served those interested in upholding white power well in their efforts to designate blackness in the court of law, yet after its integration, they abandoned it albeit begrudgingly. While some doctors, blood collection agencies, and hospitals primarily in the South refused to follow the ARC's integration policy, most were forced to give up on blood as a way to categorize race. For in its new irreversibly mixed form, blood could no longer uphold the fiction of white purity. As the body became an increasingly unstable location for race identification, Americans would witness - and some would take part in - utilizing culture instead of blood to differentiate white from other. The shift in focus from blood to culture revealed the fluidity of race and the disturbing adaptability of the categories used to uphold white power.

\section{Blood, Race, and the ARC's Labeling Scandal}

In the United States, blood played a critical if unstable role in categorizing the supposed difference between white and black. In the 1800s, slavery proponents justified the practice by stigmatizing black blood as a contaminant. In 1851, physician Samuel Cartwright described a disease "peculiar to negroes" whereby a lack of "red, vital blood . . . chain[ed] the mind to ignorance and barbarism, when in freedom." In his proslavery deduction, the only cure for the disease he named "dysaesthesia aethiopica" was to place black men and women under the supervision of white men and force them into physical labor, actions that would purportedly help "red, vital blood" reach the brain. Cartwright's Confederate contemporaries agreed that "negro ineptitude" was a symptom of blood and nerve disease. ${ }^{3}$

Blood took on even greater significance after emancipation when, as described by Eva Saks, black skin ceased to signify slave status. ${ }^{4}$ Saks astutely demonstrates how, in the late 1800s and early 1900s, blood became a potent symbol used to argue that race was not what appeared on the outside but rather was constituted within the body. For those vested in white power, race turned inward, and blood came to designate race by collapsing ideas of heredity, kin, and community - a binding fictive relationship that grew dangerously naturalized over time. ${ }^{5}$

During the first half of the twentieth century, pseudoscientific logic that linked blood to race carried far-reaching social and legal effects. In the court of law, blood became a designator of race used to classify individuals as nonwhite, racial evidence that was then used to deny those individuals the right to naturalize or own property. ${ }^{6}$ Antimiscegenation laws repeatedly turned to a combination of appearance and blood pedigree to deny interracial marriage, primarily between white and black couples but also between white and Asian, Mexican, 


\section{Susie Woo}

or Native American couples. ${ }^{7}$ Peggy Pascoe shows that plaintiffs, defendants, lawyers, and judges manipulated blood to prevent and dissolve interracial marriages until 1967 when the Supreme Court ruled in Loving v. Virginia that the practice was unconstitutional. Pascoe convincingly argues that using blood for these purposes was more than just another form of segregation; it was the very foundation of white supremacy that relied on the fiction of white purity to sustain power. ${ }^{8}$

Even though eugenic theory was on the wane by the 1940s and scientific studies refuted the correlation between blood and race, decades of social training made it difficult for many to shake the idea that blood and race were synonymous. Nowhere was this more evident than in discussions about blood transfusions. As transfusion technology improved in the 1940s and the practice grew more common, some wondered if transfused black blood would racially alter white patients. If the effects did not manifest immediately, then perhaps they would down the road when grandchildren and great-grandchildren would be born with "Negro" characteristics. ${ }^{9}$ In 1942, Mississippi Senator John Rankin declared that if blood transfusions were integrated, race and especially whiteness would become "mongrelized." 10 Concerns like these reflected both the newness of blood transfusions and the core fear of white segregationists. For if race failed to remain distinct at the level of blood, how could one identify the difference on which white power relied? If white blood were indiscriminately mixed with black blood, would there be any value left to whiteness?

The historic use of blood as a naturalized location of race complicated transfusion protocol starting with the first national blood drive during World War II. In November 1941, the ARC officially announced that it would exclude African American donors. Two months later, following significant criticism, the organization altered its policy to accept African American blood but only if it remained segregated. ${ }^{11}$ As Thomas Guglielmo has demonstrated, the ARC based its decision to separate black blood on the wishes of a general (white) public who would supposedly not stand for blood integration. ${ }^{12}$ Administrators explained that because of the state of race relations and the novelty of transfusions, accepting white and black blood together proved politically untenable. The ARC further reasoned that since the US Army was segregated, it would be best for the morale of white soldiers if the ARC did not collect African American blood. ${ }^{13}$ The ARC's stance was hardly unique during a time of Jim Crow. Cities often set up separate ambulance companies, one for white and one for black patients; some hospitals denied service to African Americans outright; and, despite the ARC's policy to label and segregate blood, many blood donation centers did not accept "Negro blood" at all. ${ }^{14}$

Several well-respected organizations publicly refuted the ARC's policies. In 1941, the National Medical Association criticized the unscientific premise of blood segregation and argued that blood types, not race, determined successful transfusions. ${ }^{15}$ A year later, the American Association of Physical Anthropologists (AAPA) released a statement that "prejudice against Negro blood" was all 
the more difficult to understand because "many a Southerner was nursed at the breast of a Negro mammy." The committee continued that it made no sense that Americans opposed African American blood but not that of horses and rabbits whose blood serum was used to cure human cases of diphtheria and pneumonia. ${ }^{16}$ The AAPA's statement brought into clear focus the contradictions of the ARC's segregation policy. By offering up examples of intimately exchanged fluids between whites, blacks, and even nonhuman species, the AAPA set out to prove the absurdity of segregating black blood.

During the war, hundreds wrote the ARC, President Franklin Roosevelt, First Lady Eleanor Roosevelt, and the surgeons general of the army and navy to criticize the antidemocratic policy. ${ }^{17}$ They protested in more public ways as well. In 1942, the March on Washington movement gathered 20,000 people in New York City to condemn the Jim Crow policies of the ARC and the military. ${ }^{18}$ Seeing how integral the blood transfusion debate was to African American claims to citizenship, the National Association for the Advancement of Colored People (NAACP) used the ongoing war as a backdrop to show how blood segregation undermined the goal of equality and threatened to mirror the evils of Nazi ideology.

In response to the sharp criticism, the ARC publicly abandoned its bloodlabeling policy in $1943 .{ }^{19}$ However, privately and just a year later, it implemented the Dedication Label Plan, instructing workers to once again label black blood but this time to do so "inobtrusively [sic], preferably after the donor ha[d] gone." ${ }^{20}$ Black blood was to be labeled with "AA" for "Afro-American," while nonblack blood, including that of other people of color, was to remain unmarked. ${ }^{21}$ Walter White, executive secretary of the NAACP, wrote the chairman of the ARC demanding that it made no sense for the ARC and the military to mix Asian blood with white blood while requiring the separation of black blood. ${ }^{22}$ Publicly, little controversy surrounded the intermixture of Asian, Latino, and Native American blood with white patients. ${ }^{23}$ However, donor center confusion about the labeling protocol for other nonwhite donors reflected the arbitrariness of labeling only African American blood.

The reasons for singling out black blood varied. To begin, the sheer need for blood during World War II far exceeded the number of donors, which made it logistically challenging for the ARC to separate all nonwhite blood according to race. ${ }^{24}$ Since the total population of those who were neither black nor white in the United States remained relatively small, the donor pool for other racial minorities was not significant, making specific policies surrounding their blood impractical. ${ }^{25}$ Racial hierarchies also played a role. Ambiguity surrounding the labeling practices of Asian, Latino, and Native American donors clarified that it was not necessarily the nonwhiteness of blood that mattered as much as its blackness, the latter the only group that collection agencies were consistently instructed to label and keep separate. The long history of blood and race in the United States shaped the stigma against black blood in particular. 
As described earlier, white supremacists defined black bodies as a threat to whiteness and argued that a single drop of black blood was enough to contaminate white purity. ${ }^{26}$ Nonblack racial minorities figured differently in US racial logic and according to eugenic theories did not espouse the same virility as African Americans. For example, orientalist histories of US paternalism and empire made Asian Americans seem docile in comparison, characteristics superimposed on biological imaginings of effete Asian bodies. ${ }^{27}$ The racially constructed weakness of nonblack minorities made their blood less potent and therefore admissible, even if not ideal, as donors to white recipients. It is important to remember that like antimiscegenation laws that prevented whites from marrying nonwhites but allowed nonwhites to intermarry freely, blood transfusions between African Americans and other nonwhite groups were permissible. Daniel Inouye writes in his autobiography that he received black blood when injured during World War II. That a Japanese American who could potentially give blood to a white person could also be the recipient of black blood suggests that the primary goal of blood labeling was not necessarily to keep black blood out of the donor pool but rather to keep black blood from directly entering white bodies specifically. ${ }^{28}$

In 1945 when the war ended, the need for blood declined, but labeling practices continued unabated. While still very much a civil rights issue, escalating Cold War pressures muted public debates surrounding segregated transfusions. The US government created the Federal Loyalty Program in 1947 and indicted individuals who espoused racial equality on the grounds that they toed the Communist Party line. In this context, open criticism of the ARC's bloodsegregating policy served as evidence of one's communist affiliations. In 1955, for example, the program indicted Dorothy Bailey, a US Employment Service worker, in part for openly criticizing the ARC's blood-segregating practices. A Loyalty official maintained that "objection to blood segregation [was] a recognized 'party line' technic [sic]" used to get African Americans to join the Communist Party. ${ }^{29}$ During the early Cold War, red-baiting made fighting for blood desegregation a costly liability.

Open criticism against blood labeling also brought unwanted attention on the broader failures of integration in the United States, a racial reality that marred the nation's claims to democracy. Rapid decolonization after World War II resulted in numerous "nonaligned" countries in Africa, Asia, and Latin America - nonwhite populations that in the binary logic of the Cold War would either fall to communism or choose democracy. As the United States expanded its global reach, it found it increasingly difficult to hide domestic race problems from international audiences made especially vigilant about the dangers of racism and the inhumanity of colonialism by the recent world war. This was in large part because civil rights leaders connected their struggle for equality to the US government's Cold War aims abroad. In a concerted effort to enact legislative changes at home, activists appealed to international audiences by airing America's race problems for all to see. By doing so, they effectively raised an 
important question: If Americans were racially discriminatory at home, could they support equality and democracy abroad? ${ }^{30}$

Amidst these pressures, the UN criticism of the ARC further challenged US claims to democracy. In September 1950, three months into the Korean War, 4,000 UN employees wanted to contribute blood to the war effort but refused to cooperate with any agency that required the racial identification of its donors. In response, the ARC asked the UN committee if, rather than outright identification, the ARC could keep specially coded card files containing the "examiner's opinion of the racial background of the donor," to which the UN responded that this was "even worse." ${ }^{31}$ The ARC then offered to drop the racial question entirely as long as it could request the donor's nationality, a proposal also rejected by the UN committee, which decided not to donate blood until the problem was resolved.

Mounting domestic and international criticism, coupled with the increasing need for blood in Korea, effectively forced the hand of the ARC. On November 19,1950 , the organization finally abandoned its blood-segregating policy. One of the first things that the ARC did was to invite the United Nations to donate blood, an action that demonstrated the extent of international influence on the ARC's decision to change its policies. Within a few days of the policy change, ARC administrators released a statement that referred to blood segregation as a "fruitless controversy that had been based on a misconception." ${ }^{32}$ By downplaying the racist roots of its recent policy and minimizing the tenacity with which it had guarded blood segregation, the ARC did its best to push the damaging practice into obscurity. After all, the ARC's blood-labeling scandal was hardly a "fruitless controversy," and the reasons for the practice were much greater than a simple "misconception." The word choice here suggested that blood should never have been separated in the first place, which in turn made the integrated blood supply seem to be a forgone conclusion. By shrouding the policy change in narratives of subtlety, the ARC muted the recent segregation of blood and its current integrated state, a process aimed at making its racist protocol appear to be a distant relic not worthy of comment.

While the ARC tried to move quickly beyond the recent blood debate, UNESCO seized the opportunity to make the incident a valuable teaching moment. In the early 1950s, UNESCO published a book series called "The Race Question in Modern Science" to discredit the linkage between race, blood, biology, and culture. In 1952, American sociologist Diana Tead synthesized the series for a "common" audience in a short book titled What Is Race? Evidence from Scientists. She used "non-technical language" and colorful illustrations in a "necessarily over-simplified form — so as to make [the scientific facts] more easily intelligible to the layman." ${ }^{33}$ The primary goal of the booklet was to teach the public that using scientific claims to justify the domination of one group over another was dangerous and even deadly. Using the recent Holocaust as an example, Tead reified that the Nazi myth of Aryan superiority was supported by a similar brand of "so-called science." 34 


\section{Susie Woo}

In her section on blood, Tead dispelled phrases like "Blood will tell," "That girl comes from a family of good blood," and "I understand there is Jewish blood in his family" (emphasis in the original). Tead averred that the confusion about blood in relation to race and superiority was a "hangover from the days before scientists had discovered genes." ${ }^{35}$ Tead then explicated the latest findings about blood backed by modern science, not superstition. In a diagram depicting the universal properties of blood, three variously shaded human shapes with tints ranging from black to gray stood side by side [Figure 2]. Lines connected the blood types to all of the differently shaded (or raced) individuals. The simplicity of the drawing did not convey the details of blood transfusions but rather drilled the point that "people of all races can be found in each blood group" and, judging from the identically large red hearts, the capacity for acceptance. Given the UN interest in the recent US blood-segregating scandal and that Tead was an American familiar with the debate, the diagram spoke directly to recent ARC policy changes.

While UNESCO spotlighted the scientific and social soundness of the newly integrated blood supply, southern ARC branches stubbornly held on to segregating practices, making it difficult for the ARC to fully lay the controversy to rest. Alabama, Arkansas, Florida, Georgia, Louisiana, and Mississippi refused to stop blood-labeling practices. In 1951, violent demonstrations broke out in Alabama as protesters railed against continued blood segregation. Several well-

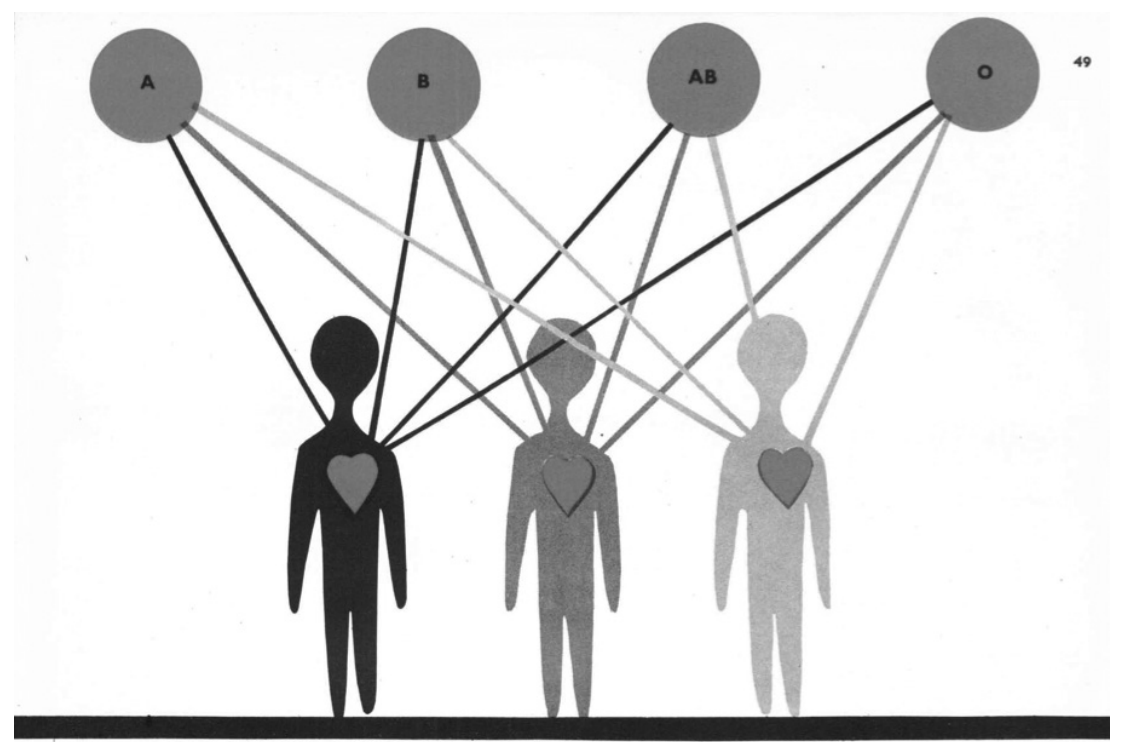

PEOPLE OF ALL RACES CAN BE FOUND IN EACH BLOOD GROUP

Individuals from any race can give blood to those from any other race-but only according to the Blood Transfusion Chart (page 50).

Figure 2: Diana Tead, What is Race? Evidence from Scientists (Paris: UNESCO Department of Mass Communication, 1952), 49. 
known white members of the state ARC resigned in solidarity with the protestors. ${ }^{36}$ The NAACP accused Alabama's ARC units of "obviously extending the segregated pattern unnecessarily and without any democratic justification." ${ }^{37}$ Public criticism against donor centers and hospitals that continued to label blood after 1950 remained localized primarily in the South, but the Korean War highlighted the national implications of southern segregating practices.

The Korean War was America's first hot war of the Cold War era, and for many it served as a litmus test to measure the behavior of the United States as a new superpower. Domestic and international audiences were critical of President Truman's entry into Korea's civil war. From the outset, it became an imperative of Truman's administration to assuage accusations of US imperialism. In a speech addressing the Korean War in 1951, Truman assured the public that the United States did "not want Formosa or any part of Asia for ourselves" reiterating that " $[\mathrm{w}] \mathrm{e}$ believe in freedom for all the nations of the Far East ... [and] want to help them secure for themselves better health, more food, better clothes and homes, and the chance to live their own lives in peace." ${ }^{38}$ Truman's speech situated Korea squarely within a Cold War framework that positioned the United States as benevolent defenders of (as well as capitalist providers to) the free world. This was a hard case to make when Americans could not achieve that same freedom at home.

In 1951, an African American World War II veteran from South Bend, Indiana, wrote,

"Looking at the blood-soaked ground of the battlefields, I can't say that I remember being able to tell colored blood from white or vice versa. My blood is as good as that of any white man. . . . If Memphis' Red Cross refuses Negro blood because it is Negro, they are a shame to the cause of humanity and democracy." 39

The veteran's words carried extra weight in the context of the ongoing war in Korea and encapsulated the core significance of blood desegregation for civil rights proponents. It was not just a matter of equality; it was about "humanity and democracy." The language used here spoke to America's broader Cold War aims. By emphasizing the damage wrought by southern ARC holdouts on African Americans, the veteran also pointed to the practice as a poor reflection on US democracy and the nation as a whole.

Public criticism of the ARC centers that continued to segregate pressured the organization to conduct its own investigation in $1951 .{ }^{40}$ The process was largely symbolic, as the ARC administered the study from start to finish even as it outright denied that segregation existed in any part of their program. Not surprisingly, the investigation yielded few results, and southern blood banks continued to label black blood. In 1960, Arkansas, Georgia, and Louisiana passed legislation that required hospitals and physicians to inform recipients of the 
race of blood donors. ${ }^{41}$ In 1962, the Alabama House of Representatives voted sixty-nine to seven to keep the state's blood banks segregated. The overwhelming victory was due in large part to state representative and practicing chiropractor Ashby Camp's argument that "negro blood was known to have a defect not prevalent in white blood." ${ }^{\prime 42}$ The chiropractor's vague assertion showed that it took very little "scientific" evidence to convince southerners of the need to keep white and black blood separate.

With casualties mounting in Korea, the US government feared that ongoing controversies and contradictions within the ARC would hinder the war effort. In response, the federal government swiftly moved in to take a more controlling role of blood collection.

\section{After Integration: The National Blood Program Narrates Transfusions}

In 1951, a year into the Korean War, President Truman created the NBP by executive order. It was estimated that a US military meeting stiff resistance in Korea would need 500 pints of blood daily. Blood-collecting efforts could not fail, and the government stepped in to take charge of all aspects of the program to ensure that it would not. The NBP subsumed the ARC utilizing the latter's well-established infrastructure of donor centers and mobile units across the nation, but from here the NBP actively distanced itself from the ARC. The NBP explicitly stated that once the ARC or the cooperating independent blood bank collected the blood, it was given to the Department of Defense or the Federal Civil Defense Administration. "At this point," the NBP explained, "the blood [became] government property and the Red Cross responsibility for the blood [ended]. ${ }^{.43}$ In describing its process to the public, the NBP distanced itself from the controversy-riddled ARC. This literal break allowed the NBP to absolve itself from ongoing criticism of the ARC for continued blood-labeling practices in the South and also from having to address the integrated national blood supply in any substantive way.

As the first federal organization to operate with the integrated blood supply, the NBP navigated the change by actively avoiding it. In its advertising efforts, the NBP sidestepped the issue of integrated blood altogether. In the context of when the program operated - during the war in Korea and as the US government waged a global Cold War campaign - it seems curious that the NBP did not address the change at all - that it did not seize the opportunity to tout the acceptance of all races in a broader effort to promote visions of US democracy. The absence pointed to the NBP's efforts to bypass existing tensions surrounding race and blood. In an effort to garner the most donations possible, the program set out to supplant conversations about blood's segregation as well as its integration. Indeed, the extent to which the NBP elided the controversial topic of race was manifest in how it set out to repackage transfusions through narratives of whiteness, gender and sexual normativity, Cold War duty, and techno- 
logical advancement - a process that together drew blood away from racialized bodies altogether.

The NBP created its own advertising council to carefully navigate conversations about transfusions. In 1952, the council produced an in-depth manual that included scripted radio spots, posters, and press releases. In the sixty-fivepage manual, blood integration was mentioned only twice and both times in the instructions section - once to explain that it did not matter who the blood came from and another as a reminder that "members of all races [were] accepted." The passing mention of race was only for the edification of volunteers and employees who worked at the centers and would not appear in any part of the publicity materials intended for the general public.

That the topic of race went missing from the advertising segment that took up the bulk of the manual signaled the significance of this intimate site of race mixture. To allay fears of the wrong kind of mixture, NBP ads consistently promoted a singular type of donor-patient relationship. All of those pictured in the NBP manual were white. ${ }^{45}$ Print ads typically showed white women "rolling up their sleeves" and white children or servicemen as the recipients. By whitening the transfusion process from start to finish, the images helped supplant lurking fears of race mixture. Whiteness made the bodies involved in the transfusion process unremarkable, normalizing the donor to the point of erasure.

On the one hand, the absence of nonwhite individuals in the NBP publicity manual maintained the status quo. ARC campaigns during World War II similarly pictured only white donors and recipients. In the continued logic of the ARC that instituted blood-segregating policies during World War II based on the belief that Americans would not donate unless black blood was segregated, the NBP feared that Americans would stop donating because of its integration. The NBP advertising council carried forth ARC narratives of whiteness for similar purposes: to appeal to white Americans who made up the majority of the donor pool by fully erasing the specter of race mixture.

For both the ARC and the NBP, picturing the bodies of donors and recipients was central to narrating a particular version of the transfusion process. In their ads, the body became a signifier of spatial and racial order. ${ }^{46}$ By reading the bodies presented in ARC and NBP ads back to the process that they narrate, several conditions emerge. First, Asian, black, Latino, and Native American blood do not exist. All nonwhite races are excised by visualizing only white donors, patients, and medics. Second, the very substance around which the ads revolved remains unseen. There are no needles used to extract or inject blood and no vials to contain it. Both the ARC and the NBP may have avoided the more visceral aspects of transfusions to allay the fears of potentially squeamish viewers, but in all likelihood picturing blood in its anonymous, bodiless state proved detrimental to its blood-collecting efforts. For all of its magical, lifegiving properties, the public still needed to see the bodies from which the blood came and that it would presumably enter to maintain scripts of whiteness or, rather, not to see scripts of racial integration, whether real or implied. 


\section{Susie Woo}

In addition to keeping the bodies white, NBP publicity materials maintained normative constructions of gender and sexuality. Like the ARC, the NBP's advertising council understood the intimacy of transfusions and saw clearly how the ejection and injection of blood carried sexualized meaning. World War II blood drives operated on the assumption that donated blood went directly to wounded American soldiers on the front. Accordingly, the ARC appealed primarily to women to support heteronormative scripts of exchange. Posters invited women to do their part in the war by giving blood or volunteering for the ARC. Nurses donning the signature red cape sprang into action to aid American men. Even the few ARC posters that featured male medics on the battlefield appealed to female donors. In the "Now Dedicate Your Blood to a Man Overseas!" World War II campaign, donors could personalize blood by signing their name on the bottle "in honor of a husband, a son, any relative or friend in the armed forces." ${ }^{47}$

By the early 1950s, when the NBP generated its own publicity, gender carried additional weight. The end of World War II ushered insecurities triggered by shifts in traditional gender roles. Men returning from war attempted to reassert their role as breadwinners, while women who had found work in the war industry were cajoled back home to resume their place as wives and mothers. ${ }^{48}$ Like World War II, the men fighting in Korea were the primary recipients of blood, and NBP ads again appealed to female donors. But unlike World War II ARC posters, the NBP focused primarily on civilians as donors rather than nurses. In one of the posters, a white, female nurse tends to a white, female donor [Figure 3]. The reclining donor at the center of this poster was the antiRosie the Riveter. With her delicate, manicured hands and tidy kerchief, giving blood was the extent of her public contribution, after which point she could return to her primary duties back home, not the factory. Her clothing and jewelry marked her as middle class, further solidifying her place in normative domestic constructions of the 1950s. In this way, the NBP ad could be cataloged alongside other 1950s images of women presenting their new refrigerators, baking pies, or ironing, visions that helped settle the crisis of masculinity by evoking traditional gender expectations. As donors, women could contribute to the war effort without ever leaving the domestic realm. Safely contained by domesticity even when pictured outside of the home and in the donation center, the NBP's donor purged the potential diversity of blood donations with dominant scripts of gendered, middle-class respectability.

Furthermore, during the early Cold War when sexual orientation could signal communist affiliations, picturing the white, female donor assuaged fears of homosexuality. ${ }^{49}$ Imagining white women as the primary providers of blood for men fighting in Korea sustained heteronormative narratives by keeping the exchange of bodily fluids between women and men (though still without raising the specter of sexual contact itself). Thus, the image of a white woman giving blood further normalized transfusions by defusing concerns about samesex exchanges. Like whitening scripts of exchange, heteronormative narratives 


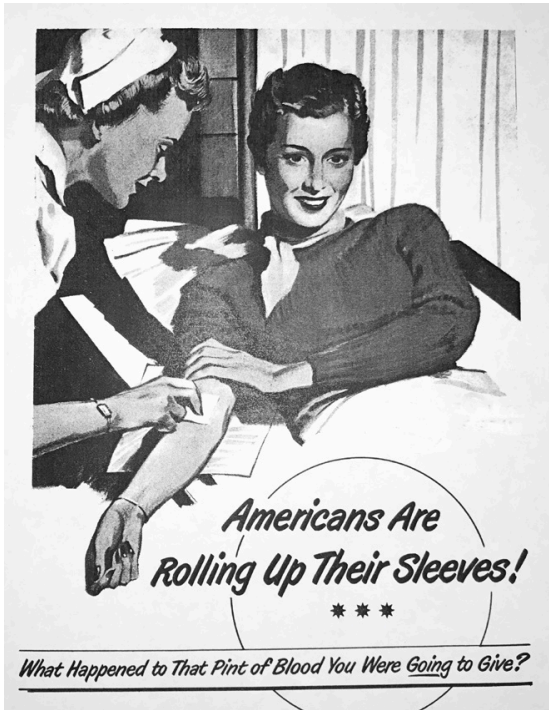

Figure 3: National Blood Program Publicity Manual (Washington, D.C.: U.S. Office of Defense Mobilization, Executive Office of the President, 1952), cover page.

leaving existing gender qualities intact. With whiteness as the shared foundation between donor and recipient and blood moving from women to men, NBP advertisements used naturalized constructions of the biological and social family to obfuscate possible concerns regarding race, gender, or sexuality in the transfusion process.

Mainstream media supported the same scripts. In Life magazine's "All Along the Front in Korea: Blood Is Flowing," images of white soldiers in Korea appear alongside text explaining the great need for blood on the front lines. The 1951 article is immediately followed by a two-page personal interest story about Margaret Burnett. An average New York City housewife, Mrs. Burnett was busy "buying wallpaper in a midtown Manhattan shop" when she saw signs to the ARC blood donation center and walked down the street to do her duty. "The nurse gently slipped a needle into a vein in her left arm," and just fifteen minutes later she filled a pint bottle. A week later, eighteen-year-old Private Richard C. Cilley was wounded by a hand grenade and desperately needed blood. Field medics in Korea received a case that traveled "by plane, truck and helicopter. They took out a pint bottle and drained it into [Cilley's] thirsty veins. . . Margaret Burnett's blood had reached its destination." ${ }^{50}$ The photographs that accompanied the article dispelled any fears that either Mrs. Burnett or Private Cilley was black. With normative race and gender constructs intact, blood 
itself became secondary to the processes surrounding it. Instead, the technology that made it possible to transport blood "halfway around the world" and the patriotism of American women like Burnett took the spotlight.

Together, the NBP's advertising council and mainstream media supplanted the integrated blood supply by normalizing transfusions as white to white and female to male. With this as the foundation, the NBP pushed forth more abstract appeals that moved blood well beyond the confines of raced, gendered, and sexualized bodies altogether. The NBP publicity manual opened with the words of George Washington: "Where is the man to be found who wishes to remain indebted for the defense of his own person and property to the exertion, the bravery, and the blood of others, without making generous effort to repay the debt of honor and gratitude." ${ }^{51}$ The quote from a man who lived well before the advent of transfusions set the nationalist tone for the entire manual. It made donating blood synonymous with Americanness. The words of one of America's founding fathers and the nation's first president made giving blood an inherently American responsibility. Those who gave blood fulfilled their civic duty, while those who did not ultimately failed the nation. That blood wielded the power to mark a person's patriotism helped to transfer associations about blood from the individual donor to the collective efforts of all Americans.

Throughout the manual, the NBP made it abundantly clear that donated blood belonged not to the individual but rather to the nation. The manual explicated for the general public that once blood left the donor's body, it was quite literally "government property." The NBP detailed the process: "Contracts with plasma processing laboratories are between the government and the laboratories. Whole blood shipped overseas is Department of Defense property and is handled and administered by Armed Forces personnel." ${ }^{2}$ Under the NBP's watch, blood was militarized. The NBP separated it from donor bodies and immediately committed the substance to the war effort. It placed donated blood squarely within the nation by putting it in the hands of the Department of Defense, the largest government agency that in 1947 consolidated the army, navy, and air force under the supervision of the secretary of state. In its radio scripts, the NBP directly connected blood in its bodiless state to national security at home and abroad. One script from the manual explicated that blood was stored outside of the body in sterile, government-owned containers that were then shipped to Korea for the war effort or stockpiled at home in preparation for a possible nuclear attack. ${ }^{53}$ While picturing vials of blood in posters was perhaps too closely associated to the body from which it came, verbally describing the pints in action for the nation appealed to donor patriotism.

While the primary goal of the NBP was to obtain blood for the Korean War, the war was not the leading rallying cry for its publicity campaign. Unlike the "Good War" of World War II, the Korean War was unpopular. By August 1950, a few months into the conflict, 49 percent of the American population thought that the war was misguided. ${ }^{54}$ By January 1, 1951, two-thirds of the American public wanted to remove US troops, and 50 percent believed that President Tru- 
man had made a mistake when he decided to enter the war. ${ }^{55}$ Pulitzer Prize-winning World War II cartoonist Bill Mauldin remarked that the Korean War was an "unglorious" one where news of soldiers killed in action might only appear in hometown papers "on page 17 under a Lux [soap] ad." Mauldin predicted that the Korean War veteran would come home not to a parade but rather quietly and alone, for "there's no victory in the old-fashioned sense, anyway, because this [wasn't] that kind of war. It [was] a slow, grinding, lonely, bitched-up war."

Most Americans felt distanced from Korea, literally and figuratively. The war took place over 6,000 miles away, and Americans knew relatively little about Korea or Koreans. These factors combined to make the threat of nuclear attack on American soil a more imminent concern for most Americans. Accordingly, the NBP appealed to domestic Cold War fears and suggested the following dramatizations for radio ads:

It is conservatively estimated that during the 3 weeks immediately following an attack during which time only 15 atomic bombs were dropped the equivalent of at least 3 million pints of blood and plasma would be required. . . Thus we see that 3 million pints represent only a small part of the total civil defense reserve that must be built up as quickly as possible... . If we are indifferent today, they will surely die if and when a black tomorrow of destruction dawns. In this age of total war, who can say: "I am safe" and convince himself he speaks the truth? $?^{57}$

What if war lashed out from behind the Iron Curtain tomorrow? Or next week? Or next Christmas? What if this war is accompanied, as it very likely would be by atomic bombs bursting over our larger and more vital cities? What if ten of our cities were hit simultaneously? Well, if it happened tomorrow there would be far from enough blood plasma to go around..$^{58}$

The NBP manual included illustrations of nuclear bomb attacks replete with mushroom plumes and parents cradling small children to add to the urgency of the call. While most of the blood collected during the NBP's existence from 1951 to 1953 was immediately sent to Korea, NBP appeals suggested that the blood would be stored at home in preparation for an imminent nuclear attack. One radio script declared, "All Americans who realize the danger to our nation from possible enemy attack should go to their Red Cross chapter and arrange to give their donation of blood for Civil Defense." ${ }^{59}$ The NBP navigated public opinion so as to garner the greatest amount of blood, and it accomplished this by teaching Americans to donate for national security. In these ways, the NBP emphasized how individual donations could support the larger whole of nation, superimposing the raceless (or assumed white) notion of patriotism and 
civic duty over the underlying controversies surrounding the racially integrated blood supply.

When it did actually describe donors, the NBP made sure to bring the conversation back to the nation rather than to the donor's body. For example, it emphasized that blood was a "miracle medicine" that only humans could produce, a fluid so rich with healing properties that the health of the nation depended on it. ${ }^{60}$ The manual asserts,

Blood is the magic gift of life. There is no substitute for it. It can only come from human donors. Remember that all weapons of war, all medical supplies and equipment needed for civil defense in an emergency can be manufactured. All, that is, except one-BLOOD. ${ }^{61}$

The NBP advertising council billed blood as a human technology that worked toward civil defense rather than as a substance that carried with it properties of kin and ancestry. By likening blood to medical supplies and equipment, it became a technology of the body, a product that only humans could manufacture. The emphasis on the magical properties of blood and its central role in national security trumped the particularities of race, gender, and sexuality.

Another NBP tactic that further pulled blood literally and symbolically away from raced bodies centered on scientific language. To begin, the manual increased its use of the term "plasma." Plasma was first popularized during World War II when the US government began researching how blood could improve medicine and society. ${ }^{62}$ As government-funded scientists discovered the useful properties of plasma, mainstream press taught audiences about the clear, yellowish, protein-rich fluid that, unlike whole blood, could be stored for long periods of time and be safely given without blood-typing. ${ }^{63}$ By the time the Korean War began and especially after blood integration in 1950, both the NBP and the ARC amplified their usage of the term. In 1951, the ARC named its national drive "Blood-for-Plasma" as opposed to simply calling it a "blood drive" as it had done in the past. ${ }^{64}$ Although whole blood was still used, in popular appeals blood became the means to retrieving plasma rather than being the means in and of itself. While blood had been linked to race for centuries, plasma had not been connected in any way to racial types, making plasma an ideal term when it came to evading the realities of integration.

During the 1950 s, mainstream press also began to pay particular attention to the scientific advancements of blood transfusions, Cold War scripts that touted the technological prowess of the United States. In 1951, Edwin J. Cohn, a Harvard University physical chemist, invented a mechanical system to collect and process human blood. The machine was made of "stainless steel, glass and plastic ... [containing] sets of centrifuges, filters and ionic exchange columns, controlled by switches, levers and pushbuttons." ${ }^{65}$ Called the "fractionator" and nicknamed the "bedside factory," doctors commended the device for its abil- 
ity to quickly separate blood components in a sealed system. ${ }^{66}$ As the machine extracted blood from the donor, the fluid ran through multiple chambers until it was mechanically transformed into elements that no longer even resembled blood. Detailed descriptions of separated, sterilized, and hermetically sealed plasma products that could be shipped and stored simultaneously disembodied and modernized blood.

In the end, the NBP escaped the perceived perils of intimate race mixture through narratives of whitened, gendered, and heterosexualized exchanges made in patriotic service to national security. And by using science and technology to help change the very properties of blood, the NBP and mainstream media modernized the substance, giving it medical meaning completely detached from its human origins. Given the reluctance of southern states to stop labeling practices, resistance that reflected deep-rooted beliefs that connected race to blood, the NBP's efforts to avoid addressing the integrated supply may have contributed to their success. During the short-lived program from 1951 to 1953, the NBP collected nearly 5 million pints of blood, an ample supply that saved ninety-eight out of every one hundred wounded soldiers transported to M.A.S.H. units during the Korean War. ${ }^{67}$

The NBP and mainstream media efforts to mitigate controversies surrounding the integration of the national blood supply by not directly naming race were symptomatic of continued assumptions about the threat of blackness. By erasing nonwhite race from the transfusion process altogether, the NBP strategically avoided the racial implications of blood integration. Indeed, it was the manual's absences that revealed the significance of mixed transfusions on racial logic that relied on blood to delineate white from black and other. Blood had been used in social and legal realms to bolster the power of whiteness for decades, making its mixture highly problematic for some. While the NBP controlled mainstream conversations about blood during the Korean War, once the program ended in 1953, medical professionals and average citizens took up the conversation, and they grappled more directly with the significance of integrated transfusions on existing notions of race.

\section{Toward Culture: Disembodying Blood and Race}

Over the course of the recent blood debates and through the Korean War, the American public had come to know quite a bit about blood types, plasma, and the transfusion process. ${ }^{68}$ By the 1950s, Americans understood blood differently. This is not to say that many did not try to sustain conversations that tied blood to race. Throughout the 1950s and 1960s, researchers published findings that pushed for a resegregation of blood. However, the studies met heavy resistance not only from medical professionals but also from the general public whose new knowledge of blood helped them dismantle the racist theories.

For example, when reports surfaced toward the end of the Korean War that donors transmitted communicable diseases to recipients, segregationists 
jumped at the chance to argue that African Americans were more prone to diseases, like sickle cell anemia and syphilis, that could be transfused to white patients. ${ }^{69}$ Susan Lederer describes how the biggest boon to such arguments came in 1959 when John Scudder, a doctor who once worked with Charles Drew, the African American doctor and coordinator of the first national blood drive in 1941, announced the potential perils of interracial transfusions. ${ }^{70}$ Scudder concluded that donors should be of the "same ethnic group as the patient's" and "of the patient's own race." ${ }^{.71}$ Aware of the controversy that his findings would bring, Scudder defended that it may have "sound[ed] wrong sociologically ... but it [was] scientifically correct." 72

Within just three days of Scudder's announcement, doctors and geneticists spoke out to discredit him. Philip Levine, the codiscoverer of the $\mathrm{Rh}$ factor, and prominent geneticists Theodosius Dobzhansky and Leslie C. Dunn, both of whom helped pen UNESCO's revised Statement on Race in 1951, proclaimed that Scudder's "so called 'new philosophy' serve[d] no useful purpose except to reinforce the old 'philosophy' of race prejudice."”3 By this point, the public was so well versed in the process of transfusions that the Columbia University doctors did not need to detail the faulty science behind Scudder's false claims. Instead, they could aim directly at the racist foundations of his study that misused science to sustain damaging myths.

To highlight the obvious fallacy of Scudder's claims, African American physician and civil rights activist Edward Mazique reiterated that there was no such thing as a "pure" race or "pure" blood to begin with. Mazique directly challenged Scudder to "scientifically ... identify his pure race before he [could] even begin the application of his new blood theory." Mazique questioned the "contention that the American Negro [was] a distinct racial group, rather than a social concept or entity." ${ }^{.74}$ Recent discoveries about blood types and the long history of race intermixture dating back to slavery tied the blood bank debate to genetic race mixture. Mazique's reference to white slave owners raping female slaves acted as a reminder that the black/white racial gene pool had already been mixed for over a century. ${ }^{75}$

The general public weighed in on the debate as well. In 1959, a Pittsburgh Courier journalist wrote that Scudder's study caused "great jubilation among white racists . . . who believed they now had scientific confirmation for their insistence that 'Negro' blood should not be administered to whites, and vice versa." "76 The journalist did not hesitate to label Scudder's supporters "white racists." Against the backdrop of the recent blood-labeling controversy, the Courier could succinctly and unhesitatingly spotlight the fabricated science on which conversations about blood historically relied. Popular discussions about blood had shifted significantly. By the 1950s, tying blood to race evidenced nothing but racist beliefs that were incorrect and outdated.

The outpouring of resistance and critiques from a range of individuals that directly named racism as the foundation for Scudder's findings made it clear that arguments linking blood to race could no longer be easily sustained. The 
blood transfusion debates of the 1940s and 1950s made it common knowledge that blood did not carry racial characteristics, findings that had broad implications for the use of blood in other arenas as well. In the court of law, racial blood quantum had been used as evidence against interracial marriage since the early 1900s. After blood's integration, cases could not easily ignore the inherent problems of using blood to designate whiteness or blackness. For example, in Loving v. Virginia, the State of Virginia threatened to dissolve the marriage of Mildred Jeter and Richard Loving. The couple's residency in Virginia went against the 1924 Act to Preserve Racial Integrity, which made it illegal for a white person to marry a colored person, the latter defined in 1910 as someone having one-sixteenth Negro blood and by 1930 as one with any ascertainable trace of Negro blood. ${ }^{77}$ The Lovings took their case to the Supreme Court, where presiding Chief Justice Earl Warren determined that attempts to "preserve the racial integrity of its citizen" by preventing "the corruption of blood" and a "mongrel breed of citizens" were considered to be "relics of slavery" and "expressions of modern day racism." 78 The Court struck down Virginia's antimiscegenation law on April 10, 1967, making it unconstitutional to deny marriage on the basis of race.

Commenting on the landmark Loving case, a Washington Post journalist asserted that there was a "nice element of absurdity" about the Virginia miscegenation statute that defined a white person as one who has "no trace whatsoever of any blood other than Caucasian." The Post argued that race purity was difficult to prove because there was "no way to determine race by blood. The blood of all humans [was] red - except when, for life-saving purposes, it [was] reduced to plasma" at which point it became "entirely colorless." ${ }^{\text {"T9 }}$ The logic and language used in the Post article demonstrated how pervasively lessons stemming from the blood integration controversy had permeated the consciousness of average Americans. The comment was testament to how popular science could drive a wedge between the deep-rooted coupling of race to blood.

Despite the NBP's efforts to downplay the racial implications of integrated blood, it was not lost on the public what bodily locations of integration meant. To compound the significance of integrated transfusions, the post-World War II era witnessed an increase in discussions about other intimate sites of race mixture that further problematized the ability of the body to delineate race difference more broadly and sustain the fiction of white purity more specifically. In 1948, the Los Angeles Times reported that one in every three marriages in Hawai' $i$ were mixed. Andrew Lind, a widely respected University of Hawai' $i$ sociologist, asserted that it was "real democracy at work" and that the time was not far off not only when it would "be impossible to maintain racial distinctions, but [also] when it [would] be desirable to use a different basis for classification." ${ }^{" 10}$ In 1952, directly following her section on blood transfusions in What Is Race?, UNESCO's Diana Tead remarked on rising genetic interraciality. Tead celebrated the tidal shift toward genetic race mixture already well under way in metropolitan centers. According to Tead, one need only sit in a "lively street 
corner café of any cosmopolitan city" to witness a "good deal of race mixture" that transformed "peoples of the earth into the present, highly variegated form." ${ }^{81}$ Lind and Tead articulated the greatest fears of segregationists: levels of race intermixture that would make existing racial categories obsolete.

On the surface, miscegenation highlighted in US media may have appeared unrelated to the integration of the national blood supply, but the shared outcomes of intimately mixed blood and genes struck a damning chord to segregationists. Together, bodily integration of blood and genes highlighted the issue that lay at the heart of race debates in the United States - mixture that muddied the ability to locate race within or even on the body. For while integrated blood transfusions made it harder to mark race difference from the inside, genetic race mixture complicated the ability to see race on the outside. Thus, whether invisible like the blood that pulsed life through one's veins or visible in the phenotype of the ambiguously mixed-race person, anxieties about uncontainable racial crossings could hardly be placated. By the 1950s, distinctions between white/black and white/other, binary relationships on which white power had relied, became increasingly blurred.

It notes remembering the integration of the national blood supply in the broader context of civil rights to understand why a change that irreversibly disarmed the ability of blood to designate race did not play a more public role in arguments for racial equality. While blood segregation was central to civil rights protests during World War II, by the 1950s discussions about it receded into the background. It could be argued that once the ARC officially integrated the blood supply in 1950, many laid the issue to rest despite southern states that continued its labeling practices. It also makes sense that fighting to desegregate schools, lunch counters, and buses, geographic places where people could publicly gather to protest and around which laws could be regulated, logically remained central to the civil rights movement as it progressed into the 1950s and 1960s. After all, physical spaces where segregating practices could be tracked with the naked eye served as a more effective battleground than the subcutaneous substance of blood.

Still, the deep symbolism of blood and the racist rulings it was used to support carried terrific weight for the civil rights movement. Since segregationist efforts were in part fueled by the anxiety that contact in public spaces might lead to intimate relationships whereby genetic and blood mixture would occur, integrated blood transfusions had the potential to discursively dismantle the entire premise of segregating policies at its core. Mixed blood suggested that the very distinctions on which racial segregation relied, black bodies and white bodies, were no longer easily identifiable as such. In the 1950s, blood became a less potent site of race, but this did not happen naturally. The concerted efforts of blood programs like the ARC and the NBP, as well as UNESCO and the mainstream press, helped drive a wedge between race and blood. Although each had its own agenda, together their efforts defused the power of blood to 
designate race, a shift that pushed blood out of the center and to the periphery of race-identifying practices.

After 1950, with millions of pints of transfused blood already anonymously mixed from within, blood could no longer be the scientific locus of race difference or, perhaps more important, the site for espousing the fiction of white racial purity. As the body increasingly failed to signal distinct differences between whiteness and blackness, those wanting to sustain white power needed to look elsewhere to find race. With blood and phenotype destabilized and the broader failure of biological science to support racist claims, race moved away from the body. Many have attributed the shift toward cultural racism beginning in the 1960s as backlash against the civil rights movement, but few include the integration of the national blood supply as a possible contributing factor. ${ }^{82}$ What the turn toward culture-of-poverty theories in the 1960s and neoconservatism in the 1970s demonstrates is the disturbing adaptability of racially discriminatory practices. ${ }^{83}$ Even as skin color and blood became increasingly unreliable locations of race, structural discrimination continued unabated in the post-civil rights era as those vested in upholding white power moved the markers of race elsewhere, outside of the body.

\section{Notes}

I wish to thank, for their invaluable insight at various stages of this article, Paul Gilroy, Megan Glick, Emily Hobson, Matthew Frye Jacobson, and Leila Zenderland. I'm especially grateful to Sherrie Tucker, Trevor Grizzell, and the anonymous readers at AMSJ for their expert guidance and constructive feedback. Thanks to the generous support of the American Council of Learned Societies New Faculty Fellows program, I was afforded the opportunity to complete the research and writing of this article.

1. In 1949, statisticians estimated that Americans would need 3.7 million pints of blood annually. G. Foard McGinnes, Ross T. McIntire, and George W. Hervey, "The National Blood Program of the American Red Cross," American Journal Public Health Nations Health 39, no. 11 (November 1949): 1431.

2. Samuel A. Cartwright, "Report on the Diseases and Peculiarities of the Negro Race," New Orleans Medical and Surgical Journal 7 (May 1851): 714.

3. Ibid., 709-12. For slavery proponents who shared Cartwright's views, see Thomas Roderick Dew, "An Essay in the Favor of Slavery" (1833), and Josiah Clark Nott, "The Negro Race: Its Ethnology and History," Anthropological Review 4 (1866): 102-18.

4. Eva Saks, "Representing Miscegenation Law," Raritan 8, no. 2 (Fall 1988): 47.

5. Keith Wailoo, Drawing Blood: Technology and Disease Identity in Twentieth-Century America (Baltimore: Johns Hopkins University Press, 1997), 137.

6. For descriptions of cases that used blood, nationality, and appearance to deny citizenship, see Ian Haney López, White by Law: The Legal Construction of Race (New York: New York University Press, 2006), 27-34 and 56-77.

7. Peggy Pascoe, "Miscegenation Law, Court Cases, and Ideologies of 'Race' in TwentiethCentury America," Journal of American History 83, no. 1 (June 1996): 45.

8. Peggy Pascoe, What Comes Naturally: Miscegenation Law and the Making of Race in America (New York: Oxford University Press, 2009), 6.

9. DeWitt Smith, the director of domestic operations for the ARC, argued that blood had to remain segregated. He based his conclusion on the letters that he received from potential donors expressing fear about the racial ramifications of mixed transfusions. Thomas Guglielmo, "Red Cross, Double Cross': Race and America's World War II-Era Blood Donor Service," Journal of American History 97, no. 1 (June 2010): 84.

10. John Rankin, "The Gentleman from Mississippi" (speech delivered to Congress on May 28, 1942), reprint from the New York PM Daily, Folder 194-43, Negro Blood File, quoted in Spencie Love, One Blood: The Death and Resurrection of Charles R. Drew (Chapel Hill: University of North Carolina Press, 1996), 194-95. 
11. For detailed descriptions of internal ARC correspondence regarding the segregation of black blood, see Guglielmo, "Red Cross, Double Cross," 69-70. See also Love, One Blood, 141, 155, and Susan Lederer, Flesh and Blood: Organ Transplantation and Blood Transfusion in Twentieth-Century America (New York: Oxford University Press, 2008), 117.

12. Guglielmo, "Red Cross, Double Cross," 65.

13. Douglas Starr, Blood: An Epic History of Medicine and Commerce (London: Little, Brown, 1998), 98. The ARC did not discuss the morale of African American soldiers; Love, One Blood, 195.

14. Keith Wailoo, Dying in the City of the Blues: Sickle Cell Anemia and the Politics of Race and Health (Chapel Hill: University of North Carolina Press, 2001), 90-91. 1942.

15. "NMA Blasts Blood Bank Segregation," New York Amsterdam Star-News, August 22,

16. Waldemar Kaempffert, "Blood and Prejudice," New York Times, June 14, 1942. For more public statements from doctors and scientists debunking the difference between white and black blood, see Guglielmo, "Red Cross, Double Cross," 78.

17. Love, One Blood, 187-88, 316 n. 23. For additional examples of civilian protest, see Guglielmo, "Red Cross, Double Cross,", 71-72.

18. "Wake Up, Negro America!!," New Amsterdam Star-News, May 30, 1942; Wailoo, Dying in the City of the Blues, 90.

19. Wailoo, Dying in the City of the Blues, 89-90.

20. "How to Set up and Operate the New Red Cross Blood Donor Dedication Label Plan," 1944, Records of the American Red Cross, National Archives and Records Administration, College Park, MD, quoted in Sarah E. Chinn, Technology and the Logic of American Racism: A Cultural History of the Body as Evidence (London: Continuum, 2000), 122-23.

21. Love, One Blood, 189. The ARC told ARC officials in Los Angeles that blood from Filipino, Chinese, and Japanese persons was to be considered "white"; Lederer, Flesh and Blood, 119-20.

22. Walter White to Norman Davis, January 27, 1942, F. Negro Blood, 1941-1943, Box 909, Group 3, Record Group 200, National Archives, Washington, D.C., quoted in Love, One Blood, $188-89,316$ n. 25.

23. Guglielmo, "“Red Cross, Double Cross,"” 73-74.

24. Blood processing centers and Army Medical Corps members admitted that blood got mixed along the way and that on the battlefield men received blood donated from all races. Ibid., 89-90.

25. According to the US Census, in 1940, African Americans made up 12,865,518 of the US population compared to 2,446,911 for American Indian, Eskimo, Asian and Pacific Islander, and those of Hispanic origin combined.

26. Neil Gotanda describes racial classifications in court cases where white is "unblemished and pure, so one drop of ancestral Black blood renders one Black." Neil Gotanda, "A Critique of 'Our Constitution Is Color-Blind,'” Stanford Law Review 44, no. 1 (November 1991): 26.

27. For more on orientalism, see Edward Said, Orientalism (New York: Vintage Books, 1979); Henry Yu, Thinking Orientals: Migration, Contact, and Exoticism in Modern America (Oxford: Oxford University Press, 2001); and Robert G. Lee, Orientals: Asian Americans in Popular Culture (Philadelphia: Temple University Press, 1999).

28. "Daniel Inouye: Blood Transfusion," Public Broadcasting Service, accessed July 29, 2015, https://www.pbs.org/thewar/detail_5293.htm.

29. Andrea Friedman, "The Strange Career of Annie Lee Moss: Rethinking Race, Gender, and McCarthyism," Journal of American History 94, no. 2 (September 2007): 449.

30. For more on domestic civil rights and the international stage, see Mary Dudziak, Cold War Civil Rights: Race and the Image of American Democracy (Princeton, NJ: Princeton University Press, 2002); Thomas Borstelmann, Cold War and the Color Line: American Race Relations in the Global Arena (Cambridge, MA: Harvard University Press, 2001); and Penny Von Eschen, Race against Empire: Black Americans and Anti-Colonialism, 1937-1957 (Ithaca, NY: Cornell University Press, 1997). 1950.

31. George Barrett, "Rift Halts Set-Up of U.N. Blood Bank," New York Times, September 8,

32. "Blood without Race," New York Times, November 22, 1950.

33. Diana Tead, What Is Race? Evidence from Scientists (Paris: UNESCO Department of Mass Communication, 1952), 4.

34. Ibid., 7.

35. Ibid., 48. Tead's use of the term "good blood" countered historic uses of the term "bad blood," the latter a phrase used by black sharecroppers to describe a variety of illnesses and also by the US Department of Public Health to describe the Tuskegee experiments conducted between 1932 and 1972; James H. Jones, Bad Blood: The Tuskegee Syphilis Experiment (New York: Free Press, 1981). 
36. "Red Cross Follows Memphis' Jim Crow Policy," Pittsburg Courier, August 4, 1951. As late as 1959, Florida, Georgia, South Carolina, and Alabama legally required racial labels on blood; Lederer, Flesh and Blood, 132.

37. "Blood Bank Bias Scorned," New York Times, September 23, 1951.

38. Harry S. Truman, Questions about the Battle in Korea, revised May 1951 (Washington, DC: Congress of Industrial Organizations, Political Action Committee), 10.

39. Letter to the editor, "Veteran Who Shed Blood Has Note on 'Refusal," Pittsburg Courier, August 18, 1951. 1951.

40. "National Red Cross Probes Memphis Blood Refusals," Pittsburg Courier, August 11, 1972.

41. Lederer, Flesh and Blood, 129-35. Louisiana upheld the segregation of blood banks until

42. "Blood Segregation Guaranteed in Alabama," Pittsburg Courier, July 21, 1962.

43. US Office of Defense Mobilization, National Blood Program Publicity Manual (Washington, DC: US Government Printing Office, 1952), 23.

44. Ibid., 21 and 24.

45. Chinn, Technology and the Logic of Racism, 121.

46. Elizabeth Abel reads segregation signs, the ones that read "White Only" and "Colored Only" in reverse to the bodies that they engage. In her exploration, she finds that language and the signs themselves came to define and control physical space. Elizabeth Abel, Signs of the Times: The Visual Politics of Jim Crow (Berkeley: University of California Press, 2010), 6.

47. "Now Dedicate Your Blood to a Man Overseas!," ARC Blood Donor Service poster in circulation from 1941 to 1945.

48. For discussions about the crisis of masculinity and gender norms during the early Cold War, see Elaine Tyler May, Homeward Bound: American Families in the Cold War Era (New York: Basic Books, 1988, 1999).

49. For investigations regarding homophobia during the Cold War, see Robert Corber, Homosexuality in Cold War America: Resistance and the Crisis of Masculinity (Durham, NC: Duke University Press, 1997), and David K. Johnson, The Lavender Scare: The Cold War Persecution of Gays and Lesbians in the Federal Government (Chicago: University of Chicago Press, 2004).

50. "Housewife's Blood Goes to a GI," Life Magazine 31, no. 17 (October 22, 1951), 26-28.

51. US Office of Defense Mobilization, National Blood Program, unnumbered, first page.

52. Ibid., 23.

53. Ibid., "Radio Script," 19. and 206.

54. Steven Casey, Selling the Korean War (New York: Oxford University Press, 2002), 35-36

55. George Gallup, The Gallup Poll: Public Opinion 1935-1971 (Westport, CT: Greenwood, 1972), 961, quoted in Soo-Ho Jung, "The Korean War and the US Public Opinion: June 1950 to January 1951" (Honors Capstone Project, American University, 2010), 1, http://aladinrc.wrlc.org/ bitstream/handle/1961/9922/Jung,\%20Soo-ho\%20-\%20Fall\%20\%10.pdf?sequence=1.

56. Bill Mauldin, Bill Mauldin in Korea (New York: Norton, 1952), 10.

57. US Office of Defense Mobilization, National Blood Program, "Blood - General Speech,"

58. Ibid., "Civil Defense Appeal," 48.

59. Ibid., 22 .

60. Ibid.

61. Ibid., 48 .

62. Wailoo, Drawing Blood, 163

63. William H. Schneider, "Blood Transfusions between the Wars," Journal of the History of Medicine and Allied Sciences 58, no. 2 (April 2003): 187-224. See also "War Surplus Red Cross Plasma Put to Civilian Use," New York Times, June 2, 1946; Waldemar Kaempfert, "Substitutes for Blood Plasma Are Tested for Use in Treatment of Wounds or Shock," New York Times, October 22, 1950; and Howard Rusk, "National Blood Program Unifies Supply for Needs," New York Times, March 23, 1952, 65.

64. "Marshall Starts Big Plasma Drive," New York Times, September 11, 1951.

65. Robert K. Plumb, “Blood Fractionation Machine, Now Perfected, Marks a Milestone in Medical History," New York Times, August 22, 1954.

66. Waldemar Kaempfert, "New Process Quickly Separates Donor's Blood into Components for Transfusions," New York Times, June 29, 1951; "Blood Processes as Donor Gives It," New York Times, May 13, 1952. The term "bedside factory" appeared in Plumb, "Blood Fractionation Machine."

67. ARC, "The American Red Cross and the Korean War," accessed July 2, 2012, http:// www.redcross.org/museum/history/korean.asp.

68. According to the National Opinion Research Center, which surveyed 2,523 white Americans in 1944, 36 percent thought that Negro blood was the same as white blood, while 32 percent thought it was different, and 32 percent said they were not sure. The broad educational efforts of 
those fighting against blood segregation affected the large percentage of white Americans who saw no difference between black and white blood. Guglielmo, "Red Cross, Double Cross," 84-85 n. 57.

69. “Government Urges Curb in Plasma Use,” New York Times, June 8, 1953. For more on the racialization of sickle cell, see Wailoo, Dying in the City of the Blues.

70. In 1940, Charles Drew developed techniques for blood storage and helped to establish the first large-scale blood banks. He was the medical director of the National Research Council, the Blood Transfusion Betterment Association, and the ARC-sponsored Blood for Britain program. According to legend, a local hospital denied Drew a blood transfusion due to his race after he was critically injured in a car accident. As a result, Drew bled to death. Disputing the legend, Spencie Love describes the accident and the ensuing treatment at the local hospital to demonstrate that Drew's injuries were too severe for doctors to save him; Love, One Blood, 17-25. For more on Charles Drew, see Lederer, Flesh and Blood, 116-17.

71. J. A. Scudder et al., "Sensitising Antigens as Factors in Blood Transfusions," Mankind Quarterly 1960: 90, 99, quoted in Michael G. Kenny, "Question of Blood, Race, and Politics," Journal of the History of Medicine and Allied Sciences 61, no. 4 (2006): 461. See also Lederer, Flesh and Blood, 123-29.

72. A. C. Wehrwein, "Blood Expert Says Transfusion between Races May Be Perilous," New York Times, November 7, 1959.

73. "Seven at Columbia Doubt Peril in Bi-Racial Blood Transfusions," New York Times, November 10, 1959; William L. Laurence, "New Procedure Advocated for Selection of Blood Types in Transfusions," New York Times, November 15, 1959.

74. Anonymous, "Scudder Blood Transfusion Controversy," Journal of the National Medical Association 52 (1960): 57, quoted in Kenny, "Question of Blood, Race, and Politics" 469. For more on Mazique, see Florence Ridlon, A Black Physician's Struggle for Civil Rights: Edward C. Mazique, M.D. (Albuquerque: University of New Mexico Press, 2005). 1962.

75. "Say 15 Million Negroes Have Crossed 'Color Line,"” Pittsburg Courier, September 1,

76. Editorial, "Reviving the 'Racial Blood' Fiction," Pittsburg Courier, November 21, 1959.

77. For more on the Loving case, see Pascoe, What Comes Naturally, 262-84; Fay Botham, Almighty God Created the Races: Christianity, Interracial Marriage, and American Law (Chapel Hill: University of North Carolina Press), 2 and 160-61; and Walter Wadlington, "The Loving Case: Virginia's Anti-Miscegenation Statute in Historical Perspective," Virginia Law Review 52, no. 7 (November 1966): 1189-223.

78. The quoted language was used in 1955 by the State of Virginia to annul the marriage between a white woman and Chinese man in Naim v. Naim, 197 Va. 80, 87 S.E.2s 749, and Loving v. Virginia, 388 US 1, 2, 3 (1967).

79. "Sanguinity," Washington Post, December 19, 1966.

80. "How Cupid Works in Hawaii," Los Angeles Times, December 6, 1948.

81. Tead, What Is Race?, 66.

82. See, for example, Michael Omi and Howard Winant, Racial Formation in the United States: From the 1960s to the 1990s, 2nd ed. (New York: Routledge, 1994), and Michael K. Brown et al., Whitewashing Race: The Myth of a Color-Blind Society (Berkeley: University of California Press, 2003).

83. Daniel Patrick Moynihan introduced the idea of a "culture of poverty" in his 1965 report. The assistant labor secretary described the urban black family as caught in an inescapable "tangle of pathology" of unmarried mothers and welfare dependency, ultimately blaming them for their own misfortune. Daniel Patrick Moynihan, "The Negro Family: The Case for National Action," US Department of Labor, accessed April 25, 2014, http:/www.dol.gov/oasam/programs/history/ webid-meynihan.htm. In the 1970s, neoconservatives argued against state intervention, such as affirmative action, on the basis that such programs challenged ideas of individualism and market-based opportunity; Omi and Winant, Racial Formation in the United States, 128-29; Nathan Glazer, "The Peoples of America," Ethnic Dilemmas, 1964-1982 (Cambridge, MA: Harvard University Press, 1983). For more on the shift toward cultural racism, see López, "Colorblind White Dominance," in White by Law, 143-62. 